\title{
PROBLEMATIKA PENERAPAN PRINSIP SUSTAINABLE DEVELOPMENT DALAM PENGELOLAAN LINGKUNGAN HIDUP DAN IMPLIKASINYA TERHADAP PEMENUHAN HAM
}

\author{
Suardi \\ Fakultas Hukum Universitas Tadulako \\ Email: suardi.ding@yahoo.co.id
}

\begin{abstract}
The principle of sustainable development in environmental management is a principle that was born out of responses to the serious environmental damages and give bad effects for human survival, the more damaged of the environment, the higher the threat to humanity itself. Therefore, development is a process of fulfilling human needs that supported on the carrying capacity of the optimal environment. Thus, the higher carrying capacity of environment makes the better stability for human life, conversely the higher human needs in life should be supported by the data support of good environment, so that it can function as a life supporting system. In the implementation, the principle of sustainable development has experienced the complex problems in implementing the balance of human life needs and also the environment, as a result, the environmental damage becomes severe and seemed not able to overcome, people assume that natural resources is the material that should be exploited for fulfilling the human needs. Therefore, environmental management geared to optimize natural resources as a supplier of material needs. By paying attention to that concept, then, environment is seen as a mere object, in turn, the environment can not be saved. Where as the concept of sustainable development requires a balance between human needs and environmental capacity. Hence, the future generations also have the right to enjoy a good and healthy environment as part of their human rights in the future. If the present generation does not pay attention those things, then, the present generation can be said violating the human rights of future generations.
\end{abstract}

Keywords: Problematic of Applying the Principle of Sustainable Development, Human Rights.

abstrak

Prinsip Sustainable Development dalam pengelolaan lingkungan hidup adalah merupakan prinsip yang lahir dari respon terhadap kerusakan lingkungan yang serius dan memberikan akibat terhadap kelangsungan hidup 
manusia di Planet Bumi ini, semakin rusak lingkungan hidup maka semakin tinggi ancaman terhadap kemanusiaan itu sendiri. Oleh sebab itu, pembangunan merupakan proses pemenuhan kebutuhan manusia secara lahiriah yang ditopang dari kemampuan daya dukung lingkungan hidup yang optimal terhadap kebutuhan manusia. Dengan demikian, sepanjang lingkungan hidup memiliki daya dukung yang tinggi maka stabilitas kehidupan manusia semakin baik pula, sebaliknya pula semakin tinggi kebutuhan manusia dalam hidupnya harus didukung dengan daya dukung lingkungan yang baik sehingga ia dapat berfungsi sebagai life suporting system. Pada tingkat implementasi prinsip Sustainable Development telah mengalami problematika yang kompleks dalam melaksanakan keseimbangan kebutuhan hidup manusia dan lingkungan itu sendiri akibatnya kerusakan lingkungan menjadi parah dan seakan-akan tak mampu di atasi, manusia menganggap bahwa sumber daya alam yang tersedia adalah materi yang harus dieksploitasi untuk kepentingan pemenuhan kebutuhan manusia yang konsumtif. Oleh karena itu, pengelolaan lingkungan diarahkan untuk mengoptimalkan sumber daya alam sebagai penyuplai kebutuhan materi semata. Dengan memperhatikan konsep tersebut maka lingkungan dipandang sebagai objek semata, pada gilirannya lingkungan tidak dapat diselamatkan. Padahal konsep pembangunan berkelanjutan mengharuskan adanya keseimbangan antara kebutuhan manusia dengan daya dukung lingkungan. Sebabnya, generasi yang akan datangpun berhak menikmati lingkungan yang baik dan sehat sebagai bagian dari hak asasi mereka yang akan datang. Bila generasi sekarang tidak memperhatikan maka dapat dikatakan generasi sekarang telah melanggar HAM generasi yang akan datang.

Kata Kunci: Problema Penerapan Perinsi Sustainable Develovment, Hak Asasi Manusia.

\section{A. Pendahuluan}

Perbincangan tentang "Pembangunan Berkelanjutan" atau "sustainable development" sebenarnya bukanlah suatu hal yang baru baik dilihat secara global maupun nasional. pembangunan berkelanjutan merupakan suatu proses pembangunan yang mengoptimalkan pemanfaatan sumber daya alam dan sumber daya manusia, dengan menyerasikan sumber daya alam dengan manusia dalam pembangunan. Namun dalam pelaksanaannya masih belum dipahami dengan baik dan oleh karenanya masih menunjukan banyak kerancuan pada tingkat kebijakan dan pengaturan terutama pada tingkat implementasi. Sebagai sebuah konsep, pembangunan yang berkelanjutan mengandung pengertian sebagai pembangunan yang "memperhatikan" dan "mempertimbangkan" dimensi lingkungan. Dalam 
UU No. 32 Tahun 2009 dijelaskan bahwa pembangunan berkelanjutan adalah upaya sadar dan terencana yang memadukan aspek lingkungan hidup, sosial, dan ekonomi, ke dalam strategi pembangunan untuk menjamin keutuhan lingkungan hidup serta keselamatan, kemampuan, kesejahtraan, dan mutu hidup generasi masa kini dan generasi masa depan. ${ }^{\prime}$

Dalam pelaksanaan konsep pembangunan berkelanjutan sudah menjadi topik pembicaraan dalam konferensi Stockholm (UN Conference on the Human Environment) tahun 1972 yang menganjurkan agar pembangunan dilaksanakan dengan memperhatikan faktor lingkungan. Menurut Sundari Rangkuti Konferensi Stocholm membahas masalah lingkungan serta jalan keluarnya, agar pembangunan dapat terlaksana dengan memperhitungkan daya dukung lingkungan (eco-development). Dilaksanakannya konferensi tersebut adalah sejalan dengan keinginan dari PBB untuk menanggulangi dan memperbaiki kerusakan lingkungan yang terjadi.

Peradaban manusia yang modern dewasa ini sangat kapitalistik dan konsumtif yang tinggi telah mendorong manusia memiliki nafsu serakah terhadap sumber daya alam yang tersedia tanpa mempertimbangkan aspek keselamatan lingkungan hidup dan manusia itu sendiri. Manusia modern terjangkiti oleh penyakit hedonisme yang tidak pernah puas dengan kebutuhan materi. Hedonisme inilah yang merupakan penyebab utama terjadinya kerusakan atas lingkungan hidup dewasa ini. Di samping itu, manusia juga menganggap bahwa sumber daya alam yang tersedia adalah materi yang harus dieksploitasi untuk kepentingan pemenuhan kebutuhan manusia yang konsumtif. Oleh karena itu, pengelolaan lingkungan diarahkan untuk mengoptimalkan sumber daya alam sebagai penyuplai kebutuhan materi semata.

Hal yang sangat mengejutkan bagi para pencinta serta pemerhati lingkungan bahwa setiap hari $195 \mathrm{~km}^{2}$ hutan hujan tropis telah hilang menjadi jalan, lahan pertanian dan keperluan lainnya, ${ }^{2} 98 \mathrm{~km}^{2}$ tanah telah berubah menjadi padang pasir, 1,5 juta ton bahan buangan beracun dilepaskan ke lingkungan, 50 sampai 100 species tumbuhan dan binatang punah akibat penggundulan hutan. ${ }^{3}$ Meningkatnya populasi manusia yang puluhan bahkan ratusan ribu orang per hari telah meningkatkan kebutuhan untuk makanan, air, perumahan, dan sumber lainnya. Akibat semua di atas,

\footnotetext{
1 Pasal 1 ayat (3) Undang-Undang Nomor 32 tahun 2009 tentang Perlindungan Dan Pengelolaan Lingkungan Hidup.

${ }^{2}$ Myers terpetik dalam Yusuf Hilmi Adisendjaja, Analisis Dampak Pembangunan Terhadap Lingkungan Suatu Tinjauan Ekologis, makalah yang disampaikan pada acara Musyawarah Kerja Nasional Jaringan Himpunan Mahasiswa Biologi Indonesia dan Seminar Lingkungan Hidup Bandung, 29 September 2003, hlm. 1.

${ }^{3}$ Ibid.
} 
maka planet bumi menjadi lebih panas, hujan menjadi sedikit asam, dan jaringan kehidupan menjadi tercabik-cabik. ${ }^{4}$

Berdasarkan angka statistik di atas para pengamat menyimpulkan bahwa: masyarakat manusia sedang menuju kepada kepunahan. Hal ini bukan hanya manusia sedang berada dalam malapetaka yang sangat besar tetapi manusia tak mampu lagi hidup di planet bumi setelah malapetaka lingkungan telah berlangsung sejak lima sampai enam dekade yang lalu. Kondisi seperti sekarang ini bila dilihat sepintas seolah-olah manusia harus memilih satu di antara dua pilihan, yaitu: apakah membangun dan berkembang terus dengan kemungkinan menjadi punah atau berhenti di tempat (stagnant) dengan segala kemiskinan yang diakibatkan oleh status quo tidak berkembangnya itu. Akan tetapi, jika dikaji lebih mendalam sampai kepada akar permasalahannya (root causesnya) tak menutup kemungkinan akan ada perspektif pemikiran baru untuk memecahkan masalah yang dihadapi. ${ }^{5}$

Kenyataan yang ada sekarang dan bahkan sejak lima dekade lalu, angka laju pertambahan populasi manusia masih tinggi kira-kira $1,8 \%$ per tahun. Hal ini tentu akan memacu pemenuhan kebutuhan manusia dengan cara mengeksploitasi sumber daya dengan dibantu kemajuan ilmu dan teknologi. Akibatnya lingkungan alami yang bebas pengaruh manusia semakin berkurang dan lingkungan buatan yang dikenai pengaruh manusia makin bertambah. Selain itu, akibat eksploitasi sumber daya dan industrialisasi untuk memacu pertumbuhan ekonomi telah menghasilkan akibat sampingan utama, yaitu menurunnya ketersediaan sumber daya dan kualitas lingkungan. Hal ini pula yang menjadi tantangan kita semua dan bagaimana seharusnya kita menyikapi serta berperan aktif di dalam menghadapi tantangan ini. ${ }^{6}$

Dinamika pembangunan nasional pada satu sisi diharapkan memberikan konstribusi bagi peningkatan kualitas kesejahteraan hidup masyarakatnya, tetapi pada sisi lain juga dapat menimbulkan kekhawatiran terhadap merosotnya kualitas lingkungan hidup secara permanen dalam jangka panjang. Kekhawatiran ini cukup beralasan, karena kenyataan menunjukan bahwa lingkungan hidup di negeri ini belum aman terhindar dari ancaman dan pencemaran serta perusakan lingkungan hidup. Alasan untuk kepentingan pembangunan pemanfaatan terhadap eksploitasi sumber daya alam telah menempatkan sebagai pemasok pendapat negara terbesar kedua setelah sektor miyak dan gas bumi. Hal tersebut telah menyebabkan terjadinya kerusakan lingkungan hidup khususnya pada lahan hutan yang hebat dan tidak terelakan, yang pada akhirnya menimbulkan kerugian

\footnotetext{
${ }^{4}$ Ibid.

${ }^{5}$ Ibid.

${ }^{6}$ Ibid.
} 
terhadap bangsa Indonesia sendiri. Hingga saat ini, perkiraan terhadap kerusakan lahan hutan Indonesia telah mencapai 56,98 Juta ha $^{7}$ dari 120,35 juta haluas hutan yang ada. ${ }^{8}$ Parahnya kerusakan hutan tersebut, di kemudian hari menimbulkan gangguan terhadap keseimbangan ekosistem lingkungan. Akibatnya, pada musim hujan timbul banjir dan erosi sebagaimana terjadi, misalnya di Jember, Jawa Timur dan Sinjai, Sulawesi Selatan beberapa waktu lalu dan beberapa daerah lainnya di Indonesia, kekeringan yang berkepanjangan, bahkan pemanasan global yang pada analisis terakhir dapat menyengsarakan umat manusia. ${ }^{9}$

Dalam perkembangan ilmu pengetahuan, teknologi, dan industri telah membawa berbagai kemajuan terhadap peradaban manusia, tetapi sekaligus melahirkan pula risiko-risiko dalam kehidupan yang sekaligus berakibat jauh dan panjang. Risiko kerawanan lingkungan hidup adalah salah satu contoh aktual. Fenomena pencemaran lingkungan hidup akibat buang limbah industri misalnya, tetap mengancam eksistensi kelestarian fungsi lingkungan hidup dalam jangka panjang, seiring dengan dinamika dan intensistas kegiatan sector industry memperkokoh kehidupan ekonominya memasuki perdagangan bebas yang kompotitif ini. ${ }^{10}$

Kedua fenomena di atas menggambarkan bahwa pola kebijakan pembangunan yang hanya berorientasi ekonomi pada pengelolaan sumber daya alam, akan menimbulkan dampak kerusakan lingkungan yang luar biasa pada gilirannya merugikan manusia, tentunya hal ini bukan merupakan kehendak bersama untuk menciptakan kondisi alam yang tidak dapat melaksanakan tugasnya sebagai Life supporting system.

Kebijakan pembangunan yang hanya berorientasi ekonomi dalam pengelolaan sumber daya alam, akan menimbulkan kerusakan lingkungan yang berdampak terhadap manusia, seperti bencana banjir, erosi, dan pemanasan global. Paradigma pembangunan seperti itu tidak dapat dipertahankan lagi, dan harus diubah karena yang demikian itu tidak saja memberikan keuntungan ekonomi, tetapi juga akan menimbulkan perubahan-perubahan terhadap lingkungan fisik dan sosial budaya yang memerlukan pengamanan secukupnya agar tidak merugikan dalam jangka panjang. ${ }^{11}$

Selanjutnya, Daud Silalahi mengatakan bahwa konsep pembangunan yang dilaksanakan sekarang tidak cukup hanya mempertimbangkan

\footnotetext{
${ }^{7}$ Konservasi hutan dan Pengurangan Utang, Harian Kompas, 19 Januari 2002.

${ }^{8}$ Hutan terkikis Industri Kehutanan pun Terpangkas, harian Kompas, 20 September 2003.

${ }^{9}$ Sulbadana, Prinsip hukum Pelestarian Hutan dan Kaitannya Dengan Pemanasan Global, (Unpad Press, 2010), hlm 2.

${ }^{10}$ Ibid

${ }^{11}$ Daud Silalahi, lingkungan Sebagai Subjek Hukum dan Kewenangan LSM Lingkungan. Hukum dan Pembangunan, N0. Agustus 1989. hlm.16.
} 
perbandingan biaya keuntungan, (cost-benefit ratio) saja, atau mekanisme pasar saja, tetapi juga memperhitungkan ongkos-ongkos sosial yang timbul (Social Cost). Misalnya, pengusaha masih menganggap lingkungan sebagai benda bebas yang dapat digunakan sepenuhnya untuk memperoleh laba yang sebesar-besarnya dalam waktu yang relatif singkat. Akan tetapi, masyarakat sebagai keseluruhan akan melihat lingkungan sebagai bagian dari kekayaan nyata yang tidak dapat lagi diperlakukan sebagai suatu benda bebas. ${ }^{12}$

Kerusakan lingkungan pada tingkat nasional, sesungguhnya demikian juga keadaan pada tingkat internasional terutama di negara-negara maju. Perubahan iklim akibat pemanasan global, disebabkan oleh pesatnya kemajuan dan pemanfaatan teknologi oleh negara-negara maju, terutama teknologi dalam bidang industri. Industri negara-negara maju yang merupakan tulang punggung perekonomian dan telah membawa mereka kepada kemajuan dan kemakmuran, digerakan oleh energi yang menggunakan bahan bakar minyak dan gas bumi serta batu bara yang kemudian menghasilkan gas emisi karbon. Konsumsi energi yang boros oleh industri negara-negara maju, telah menyebabkan terjadinya pemanasan bumi pada tingkat yang mencemaskan. ${ }^{13}$

Menelaah lebih jauh dari problematika tersebut di atas, menunjukan bahwa secara harfiah baik peningkatan kualitas kesejahteraan hidup masyarakat maupun tindakan untuk mencegah terhadap merosotnya kualitas lingkungan hidup adalah kedua-duanya merupakan tanggung jawab negara dalam pemenuhan hak konstitusional warga negaranya dibidang hak asasi manusia, hal ini dapat ditemukan dalam Konstitusi Negara Republik Indonesia. Dalam Pasal 28 H ayat (1) UUD 1945 berbunyi "Setiap orang berhak hidup sejahtera lahir dan batin, bertempat tinggal, dan mendapatkan lingkungan hidup baik dan sehat serta berhak memperoleh pelayanan kesehatan". Hak untuk hidup sejahtera dan memperoleh lingkungan yang baik dan sehat terintegrasi dalam satu pasal, arti dalam penempatan ini bahwa keduanya dalam hidup manusia memiliki derajat yang sangat menentukan tentang keberlangsungan hidup manusia itu sendiri.

Mencermati berbagai problematika antara eksploitasi lingkungan yang berdampak menurunnya kualitas lingkungan sehingga tidak bisa berfungsi sebagai sistem pendukung kehidupan (life supporting system) dan di sisi lain peningkatan kesejahteraan manusia adalah mutlak dan pada akhirnya lingkungan sebagai sumber materiil tidak bisa terhindar dari eksplorasi dan eksploitasi yang berimplikasi terhadap kerusakan dan pencemaran lingkungan, yang oleh banyak orang dianggap suatu pelanggaran hak asasi

${ }^{12}$ Ibid, hlm. 17.

13 Suardi dan Muhammad, Tanggungjawab Negara Terhadap Pemenuhan Hak Atas Lingkungan Yang Sehat dan Bersih Dalam Prespektif Hak Asasi Manusia, laporan hasil peneitian, Fakultas Hukum Universitas Tadulako Tahun 2014, hlm, 8. 
manusia. Berangkat dari uraian tersebut di atas, maka pada pembahasan selanjutnya akan membatasi pada masalah sebagai berikut: 1) bagaimana problematika penerapan Prinsip Sustainable Development dalam pengelolaan lingkungan?; dan 2) apakah implikasi problematika tersebut dalam pemenuhan Hak Asasi Manusia?

\section{B. Pembahasan}

\section{Pengertian dan Urgensi Prinsip Sustainable Development dalam} Pengelolaan Lingkungan.

Pembangunan berkelanjutan adalah terjemahan dari Bahasa Inggris, sustainable development. Istilah pembangunan berkelanjutan diperkenalkan dalam World Conservation Strategy (Strategi Konservasi Dunia) yang diterbitkan oleh United Nations Environment Programme (UNEP), International Union for Conservation of Nature and Natural Resources (IUCN), dan World Wide Fund for Nature (WWF) pada 1980. Pada 1982, UNEP menyelenggarakan sidang istimewa memperingati 10 tahun gerakan lingkungan dunia (1972-1982) di Nairobi, Kenya, sebagai reaksi ketidakpuasan atas penanganan lingkungan selama ini. Dalam sidang istimewa tersebut disepakati pembentukan Komisi Dunia untuk Lingkungan dan Pembangunan (World CommissiononEnvironment and Development WCED). PBB memilih PM Norwegia Nyonya Harlem Brundtland dan mantan Menlu Sudan Mansyur Khaled, masing-masing menjadi Ketua dan Wakil Ketua WCED. Menurut Brundtland Report dari PBB (1987), Salah satu faktor yang harus dihadapi untuk mencapai pembangunan berkelanjutan adalah bagaimana memperbaiki kehancuran lingkungan tanpa mengorbankan kebutuhan pembangunan ekonomi dan keadilan sosial. ${ }^{14}$

Dalam laporan yang dikeluarkan oleh Commission Perserikatan Bangsa-Bangsa untuk lingkungan dan pembangunan pada tahun 1987 yang diketuai oleh Gro Brundtland (Perdana Menteri Norwegia) ${ }^{15}$ yang berjudul "Hari Depan Kita Bersama" (Our Common Future) yang menjadi tonggak pembangunan berkelanjutan (sustainable development) dirumuskan pengertian pembangunan berkelanjutan adalah "Pembangunan yang dilakukan untuk memenuhi kebutuhan sekarang tanpa mengabaikan hak

\footnotetext{
${ }^{14}$ Dewan Redaksi, Online bulleting, edisi Januari-Pebruari 2009, tata ruang, Gerakan Kota Hijau.

15 Otto Soemarwoto, Ekologi, Lingkungan Hidup dan Pembangunan. Penerbir Jembatan, Cetakan kesepuluh, 2004, hlm. 161-162. Selanjutnya komisi ini lazim disebut dengan Komisi Brundtland. Komisi ini bertugas untuk menganalisis dan memberi saran bagi proses pembangunan berkelanjutan. Komisi ini terdiri dari 9 orang mewakili negara Maju dan 14 orang mewakili negara berkembang. Salah satunya anggotanya adalah Emil Salim dari Indonesia. Yang pada waktu itu menjabat sebagai Menteri Kependudukan dan Lingkungan Hidup.
} 
generasi mendatang untuk memenuhi kebutuhan mereka" ("development that meets the needs of the present without compromising the ability of future generations to meet their own need").

Menurut Otto Sumarwoto faktor lingkungan yang diperlukan untuk mendukung pembangunan yang berkelanjutan ialah: Pertama, terpeliharanya proses ekologi yang esensial; kedua, tersedianya sumber daya yang cukup; dan ketiga, lingkungan sosial budaya dan ekonomi yang sesuai. Ketiga faktor itu tidak saja mengalami dampak dari pembangunan, melainkan juga mempunyai dampak terhadap pembangunan. Oleh karena itu, pembangunan berkelanjutan didefinisikan sebagai "Perubahan positif sosial ekonomi yang tidak mengabaikan sistem ekologi dan sosial di mana masyarakat bergantung kepadanya. ${ }^{16}$ Keberhasilan penerapannya memerlukan kebijakan, perencanaan, dan proses pembelajaran sosial yang terpadu, viabilitas politiknya tergantung pada dukungan penuh masyarakat melalui pemerintahannya, kelembagaan sosialnya, dan kegiatan dunia usahanya".

Selanjutnya, menurut Emil Salim pembangunan berkelanjutan (sustainable development) diartikan sebagai suatu proses pembangunan yang mengoptimalkan manfaat dari sumber daya alam dan sumber daya manusia dengan menyerasikan sumber alam dan manusia dalam pembangunan. Lebih lanjut ia mengatakan, konsep pembangunan berkelanjutan ini di dasari oleh lima ide pokok besar, yaitu: Pertama, proses pembangunan mesti berlangsung secara berlanjut, terus-menerus, dan kontinu, yang ditopang oleh sumber alam, kualitas lingkungan, dan manusia yang berkembang secara berlanjut pula; Kedua, sumber alam (terutama udara, air, dan tanah) memiliki ambang batas, di mana penggunaannya akan menciutkan kuantitas, dan kualitasnya; Ketiga, kualitas lingkungan berkorelasi langsung dengan kualitas hidup;Keempat, bahwa pola penggunaan sumber alam saat ini mestinya tidak menutup kemungkinan memilih opsi atau pilihan lain di masa depan; dan kelima, pembangunan berkelanjutan mengandaikan solidaritas transgenerasi, sehingga kesejahteraan bagi generasi sekarang tidak mengurangi kemungkinan bagi generasi selanjutnya untuk meningkatkan kesejahteraannya pula. ${ }^{17}$

Lebih lanjut Emil Salim mengatakan untuk melaksanakan pembangunan berkelanjutan dibutuhkan pendekatan ekosistem dengan melihat interdepedensi dari setiap komponen ekosistem. Agar keberlanjutan tetap terjaga harus ada komitmen setiap komponen penyangga kehidupan dan campur tangan pemerintah dengan melibatkan lembaga swadaya masyarakat. Dunia usaha yang selama ini dituduh sebagai pelaku yang menimbulkan kerusakan dan pencemaran harus dipahamkan akan

\footnotetext{
${ }^{16}$ Ibid.

${ }^{17}$ www. Bangazul.com./prinsip-prinsip pembangunan berkelanjutan.
} 
tanggungjawabnya terhadap lingkungan yang dapat diwujudkan dalam bentuk membayar kompensasi jasa lingkungan yang nantinya dapat digunakan untuk membiayai pemulihan lingkungan yang rusak atau tercemar. Di negara-negara maju, biaya konpensasi lingkungan jauh-jauh hari sudah dianggarkan dalam rencana pembiayaan dan pengeluaran perusahaan. $^{18}$

Konsep pembangunan berkelanjutan meluas dari definisi sebelumnya sebagai isu pelestarian lingkungan menjadi berbagai isu pembangunan yang saling bersifat komplementer. Dokumen Perserikatan Bangsa-Bangsa dalam World Summit tahun 2005 menyatakan pembangunan berkelanjutan terdiri atas tiga pilar yaitu pembangunan ekonomi, pembangunan sosial, dan pelestarian lingkungan yang saling berkaitan dan memperkuat (interdependent and mutually reinforcing pillars of sustainable development as economic development, social development, and environmental protection). Ketiga aspek tersebut tidak bisa dipisahkan satu sama lain, karena ketiganya menimbulkan hubungan sebab-akibat. Aspek yang satu akan mengakibatkan aspek yang lainnya terpengaruh. Istilah berkelanjutan menjadi umum pada berbagai isu pembangunan seperti pertanian berkelanjutan, teknologi, ekonomi berkelanjutan, politik berkelanjutan, kota berkelanjutan, produksi berkelanjutan, dan sebagainya.

Menurut Otto Soemarwoto, tolok ukur pembangunan berkelanjutan secara sederhana yang dapat digunakan baik untuk pemerintah pusat maupun di daerah untuk menilai keberhasilan seorang Kepala Pemerintahan dalam pelaksanaan proses pembangunan berkelanjutan. Keenam tolok ukur itu meliputi:

a. pro lingkungan hidup;

b. pro rakyat miskin;

c. pro kesetaraan jender;

d. pro penciptaan lapangan kerja;

e. pro dengan bentuk negara kesatuan RI; dan

f. harus anti korupsi, kolusi, dan nepotisme.

\section{Prinsip Sustainable Developmentdalam Prespektif Hak Asasi Manusia.}

Sebenarnya HAM adalah masalah lama, akan tetapi tetap relevan dan aktual karena dari waktu ke waktu sejak manusia hadir di dunia sampai pada saat sekarang ini, hal itu terus menerus dibicarakan dan hasilnya pun tidak pernah tuntas dan lugas, melainkan senantiasa menimbulkan permasalahan baru senapas dengan perkembangan kehidupan manusia. Dia aktual secara terus menerus baik secara keilmuan, politik, maupun hukum. Hal ini

${ }^{18}$ Ibid. 
disebabkan oleh bentuk, dan pemahaman dan landasan teorinyapun berkembang. Suatu bukti bahwa HAM itu aktual dan berkembang ialah lahirnya HAM generasi III, yaitu hak atas pembangunan (right to development) di samping Sipil and Political rights generasi I dan hak ekonomi, social, dan budaya sebagai generasi ke II. ${ }^{19}$

Diskursus tentang masalah hak-hak asasi manusia akhir-akhir ini memperoleh konteksnya yang baru dalam hubungannya dengan pembangunan yang berkelanjutan serta pembangunan yang berpusat pada manusia. Keterkaitan yang esensial antara hak-hak asasi manusia dengan masalah lingkungan hidup, pembangunan dan perdamaian, akhir-akhir ini semakin diapresiasi dan di dasari oleh para penentu kebijkan, pakar dan pekerja pembangunan, pembela hak-hak asasi manusia, dan pemrakarsa perdamian. Sehingga, terjadi berbagai diskursus yang mendasar tentang konsep-konsep hak-hak asasi manusia, penjabaran dan implementasinya, situasi sosio-kultur dan historis masyarakat lokal, serta budaya asli yang konkret. $^{20}$

Pada dasarnya manusia memiliki martabat dan derajat yang sama dengan demikian memiliki hak-hak dan kewajiban-kewajiban yang sama, derajat manusia yang luhur (human dignity) itu berasal dari Tuhan yang menciptakannya. Martabat manusia yang luhur berdasarkan kenyataan bahwa manusia adalah pribadi, yang unik adanya untuk setiap manusia sebagai individu rohani. Oleh karena itu, setiap manusia harus bebas, dapat mengembangkan dirinya sesuai dengan budinya yang sehat. Apabila manusia tidak dapat melaksanakan tugas hidupnya, ${ }^{21}$ maka gagal ia sebagai manusia. Pengembangan diri manusia harus terlaksana dalam relasi dengan sesamanya dalam suasana keadilan. ${ }^{22}$

Pandangan tersebut diatas telah memberikan dasar pemikiran tentang pengertian HAM itu sendiri, yang merupakan seperangkat hak yang melekat pada hakikat dan keberadaan manusia sebagai mahluk Tuhan Yang Maha Esa dan merupakan anugerah-Nya yang wajib dihormati, dijunjung tinggi,

${ }^{19}$ Rukmana Amanwinata, Pengaturan dan Batas Implementasi Kemerdekaan Berserikat dan Berkumpul Dalam Pasal 28 UUD 1945. Disertasi, (Bandung: Universitas Padjadjaran, 1996), hlm. 1-2.

${ }^{20}$ M. Habib Chirzin, Hak Pembangunan Sebagai Hak Asai Manusia.

${ }^{21}$ Tugas manusia diciptakan oleh Allah adalah sebagai Khalifah Allah sebenarnya adalah perwakilan Allah untuk berbuat sesuai dengan misi yang telah ditentukan Allah sebelum manusia dilahirkan yaitu untuk memakmurkan bumi. Khalifah yang dimaksud Allah bukanlah suatu jabatan sebagai Raja atau Presiden tetapi yang dimaksud sebagai kholifah di sini adalah seorang pemimpin Islam yang mampu memakmurkan alam dengan syariahsyariah yang telah diajarkan Rosulullah kepada umat manusia. Dan manusia yang beriman sejatilah yang mampu memikul tanggungjawab ini. Karena kholifah adalah wali Allah yang mempusakai dunia ini.

22 A. Gunawan Setiardja, Hak-Hak Asasi Manusia Berdasarkan Ideologi Pancasila, (Yogyakarta: Kanisius, 1993), hlm, 74. 
dan dilindungi oleh negara, hukum, Pemerintah, dan setiap orang demi kehormatan serta perlindungan harkat dan martabat manusia. Prinsip dasar Hak Asasi Manusia adalah hak untuk hidup, artinya dengan kehidupanlah manusia dapat melaksanakan tugasnya sebagai khalifah dan memenuhi segala kebutuhan hidupnya sehingga kehidupan manusia di alam ini dapat berlangsung secara terus-menerus antar generasi ke generasi berikutnya sampai sepanjang zaman.

Konstruksi HAM dalam konteks sustainable development tersebut mengindikasikan bahwa pengembangan diri manusia serta kelangsungannya sangat ditentukan oleh keadaan lingkungan yang sustaiunable sepanjang manusia itu ada di alam ini. Oleh karena itu, prinsip sustainable development merupakan indikator pembangunan berkelanjutan meliputi aspek ekonomi, ekologi/lingkungan, sosial, politik, dan budaya. Dengan demikian, prinsip sustainable development merupakan bagian yang tidak dapat dipisahkan dengan prinsip-prinsip HAM itu sendiri. Hakikat sustainable development adalah untuk mendukung keberlangsungan Hak Asasi Manusia itu sendiri.

\section{Problematika Penerapan Prinsip Sustainable Development dalam Pengelolaan Lingkungan dan Implikasinya terhadap Pemenuhan HAM}

Pembangunan dengan menjadikan sumber daya alam sebagai penopang utamanya bertujuan untuk menyejahterakan kehidupan manusia dalam memenuhi kebutuhan hidupnya menuju peradaban yang lebih modern. Pembangunan terus berlangsung menimbulkan kesenjangan antara kebutuhan sumber daya alam yang terus meningkat dan beragam untuk memenuhi kebutuhan manusia dan ketersedian sumber daya alam yang terbatas serta laju pertumbuhan penduduk sangat meningkat begitu cepat seiring dengan merosotnya sumber daya alam bahkan kerusakan dan pencemaran lingkungan sangat memprihatinkan. ${ }^{23}$

Menururt Robert Malthus bahwa untuk menyeimbangkan antara pertumbuhan penduduk (kelahiran) dengan pertumbuhan pangan (produksi), mau tidak mau produktivitas pangan harus ditingkatkan. Hal ini bisa dilakukan dengan cara mengoptimalkan sumber daya alam yang dapat dikelola dalam bentuk barang dan jasa. Karena tingkat kepuasan manusia terhadap barang dan jasa bersifat tidak terbatas, maka optimalisasi pengurasan sumber daya alam dilakukan tanpa pernah memperdulikan sumber daya alam bersifat terbatas. Akibat yang timbul kemudian adalah

\footnotetext{
${ }^{23}$ Suardi. B. Dg. Mallawa. Hak Gugat Organisasi Lingkungan Hidup Dalam Sistem Hukum Lingkungan Indonesia. Jurnal Penegakan Hukum Volume 3, Nomor 2 Juli 2006. Terakreditasi berdasarkan Keputusan Direktur Jenderal Pendidikan Tinggi Departemen Pendidikan Nasional Nomor 55/Dikti/2005 Tanggal 17 November 2005, hlm, 80.
} 
proses degradasi lingkungan berupa kerusakan dan pencemaran lingkungan semakin menjadi-jadi dan bertambah parah.

Untuk mengatasi persoalan tersebut di atas, tanggung jawab manusia untuk menjaga lingkungan hidup dapat dilihat dari 3 (tiga) sudut pandang yaitu lingkungan hidup dari sudut pandang religius, sudut pandang humanism, serta sudut pandang etika dan moral. ${ }^{24}$ Menurut penulis bahwa tanggung jawab manusia untuk menjaga lingkungan agar tetap lestari berimplikasi terhadap pemenuhan hak asasi manusia itu sendiri, hal ini disebabkan karena lingkungan dan manusia saling ketergantungan. Oleh karena itu, secara harfiah prinsip sustainable development secara implisit telah terkandung unsur-unsur HAM di dalamnya. Sehingga selalu dikaitkan bahwa kerusakan dan pencemaran lingkungan hidup pada gilirannya akan menentukan kehidupan manusia antar generasi bahkan dapat dipastikan bahwa kepunahan manusia di alam ini sangat ditentukan oleh punah atau tidaknya lingkungan.

Meskipun pengetahuan tentang tanggung jawab manusia terhadap lingkungan dari sudut pandang di atas, namun tetap tidak menimbulkan kesadaran untuk melestarikan atau menjaga lingkungan. Justru yang menonjol adalah eksploitasi lingkungan untuk pertumbuhan ekonomi masyarakat, sebagaimana terlihat gencarnya pembangunan industri kehutanan dan maraknya Illegal logging. Padahal kalau memperhatikan prinsip sustainable development sudah menjadi asas dalam berbagai hukum internasional maupun nasional, namun memperhatikan kondisi lingkungan hidup pada saat ini sangat memprihatinkan itu berarti baru pada tataran konsep yang masih jauh dari kenyataan, oleh karenanya dibutuhkan kesadaran dan kesungguhan dari segenap elemen bangsa untuk mengamalkannya. ${ }^{25}$

Problemanya dalam konstruksi hukum positif sampai pada saat ini perusakan dan pencemaran lingkungan belum dikualifikasi sebagai pelanggaran HAM, kemudian apakah pelanggaran HAM biasa atau pelanggaran berat HAM semua ini harus dilihat dalam berbagai perspektif. Dalam UU 39 Tahun 1999 tentang HAM dijelaskan bahwa hak asasi manusia adalah seperangkat hak yang melekat pada hakikat dan keberadaan manusia sebagai mahluk Tuhan Yang Maha Esa dan merupakan anugrahNya yang wajib dihormati, dijunjung tinggi, dan dilindungi oleh negara, hukum, pemerintah, dan setiap orang demi kehormatan serta perlindungan harkat dan martabat manusia. ${ }^{26}$

\footnotetext{
${ }^{24}$ Syaiful Bahri Ruray, Tanggungjawab Hukum Pemerintah Daerah Dalam Pengelolaan \& Pelestarian Fungsi Lingkungan Hidup, (Bandung: Alumni, 2012), hlm. 74.

${ }^{25}$ Sulbadana, Op, Cit, hlm, 2.

${ }^{26}$ Pasal 1 ayat 1 UU N0 39 tahun 1999 tentang HAM .
} 
Kalau kita mencermati bahwa pengertian HAM dalam UU 39 Tahun 1999 tersebut sangat terbatas dan sempit karena kata "seperangkat" yang kata dasarnya "perangkat" seolah-olah membatasi pada bagian tertentu saja yaitu khusus untuk manusia, kemudian ini dipertegas dengan pengertian pelanggaran HAM adalah setiap perbuatan seseorang atau kelompok orang termasuk aparat negara baik disengaja maupun tidak disengaja atau kelalaian yang secara melawan hukum mengurangi, menghalangi, membatasi, dan/atau mencabut hak asasi manusia seseorang atau yang dijamin oleh UU ini, dan tidak mendapatkan, atau dikhawatirkan tidak akan memperoleh penyelesaian hukum yang adil dan benar, berdasarkan mekanisme hukum yang berlaku.

Dengan demikian pelanggaran HAM itu dianggap sebagai suatu pelanggaran ketika bersentuhan dengan nilai kemanusiaan itu sendiri. Oleh kerena itu, sulit sekali menganggap pencemaran dan perusakan lingkungan yang mengancam keberlangsungan hidup manusia dapat dikualifikasi sebagai suatu pelanggaran HAM, padahal dalam instrumen hukum lainnya termasuk Konstitusi mengintegrasikan lingkungan sebagai bagian dari HAM, dan bahkan lingkungan masuk dalam generasi ketiga dalam perkembangan HAM itu sendiri disamping Ham Sipol sebagai generasi Pertama dan HAM Ekonomi Sosial, Budaya sebagai generasi Kedua.

\section{Penutup}

1. Prinsip Sustainable Development merupakan suatu proses pembangunan yang mengoptimalkan pemanfaatan sumber daya alam dan sumber daya manusia, dengan menyerasikan sumber daya alam dengan manusia dalam pembangunan. Dalam pelaksanaan konsep pembangunan berkelanjutan sudah menjadi topik pembicaraan dalam konferensi Stockholm (UN Conference on the Human Environment) tahun 1972 yang menganjurkan agar pembangunan dilaksanakan dengan memperhatikan faktor lingkungan. Konferensi Stocholm membahas masalah lingkungan serta jalan keluarnya, agar pembangunan dapat terlaksana dengan memperhitungkan daya dukung lingkungan (eco-development). Dilaksanakannya konferensi tersebut adalah sejalan dengan keinginan dari PBB untuk menanggulangi dan memperbaiki kerusakan lingkungan yang terjadi. Namun, dalam implementasi pada saat kondisi sekarang adalah manusia cenderung sangat kapitalistik dan konsumtif yang tinggi telah mendorong manusia memiliki nafsu serakah terhadap sumber daya alam yang tersedia tanpa mempertimbangkan aspek keselamatan lingkungan hidup dan manusia itu sendiri. Manusia modern terjangkiti oleh penyakit hedonisme yang tidak pernah puas dengan kebutuhan materi. Inilah yang meruapakan penyebab utama terjadinya kerusakan atas lingkungan hidup dewasa ini. Di samping itu, manusia juga 
menganggap bahwa sumber daya alam yang tersedia adalah materi yang harus dieksploitasi untuk kepentingan pemenuhan kebutuhan manusia yang konsumtif. Oleh karena itu, pengelolaan lingkungan diarahkan untuk mengoptimalkan sumber daya alam sebagai penyuplai kebutuhan materi semata, dan inilah penyebab utama problematika penerapan Prinsip Sustainable Development dalam pengelolaan lingkungan;

2. sampai pada saat ini lingkungan sangat dieksploitasi secara besar-besaran tanpa memperhitungkan akibat yang ditimbulkan terhadap kerusakan lingkungan itu akibatnya lingkungan tidak dapat berfungsi sebagai Life supporting system, dalam ekosistem kehidupan manusia dan lingkungan saling ketergantungan satu sama lain. Dengan demikian, apabila lingkungan rusak atau tercemar maka terganggu pula kebutuhan manusia untuk melangsungkan kehidupan dan bahkan bisa menyebabkan manusia menjadi punah. Inilah sebabnya lingkungan dalam presfektif HAM dikategorikan sebagai HAM generasi ketiga.

\section{Daftar Pustaka}

\section{A. Buku dan Jurnal}

Adisendjaja, Yusuf Hilmi, Analisis Dampak Pembangunan Terhadap Lingkungan Suatu Tinjauan Ekologis, makalah yang disampaikan pada acara Musyawarah Kerja NasionalJaringan Himpunan Mahasiswa Biologi Indonesia dan Seminar Lingkungan Hidup Bandung, 29 September 2003.

Amanwinata, Rukmana, 1996. Pengaturan dan Batas Implementasi Kemerdekaan Berserikat dan Berkumpul Dalam Pasal 28 UUD 1945, Disertasi, Bandung: Universitas Padjadjaran,.

Chirzin, M, Habib, Hak Pembangunan Sebagai Hak Asai Manusia.

Ruray, Syaiful Bahri, 2012. Tanggung jawab Hukum Pemerintah Daerah Dalam Pengelolaan \& Pelestarian Fungsi Lingkungan Hidup, Bandung: Alumni.

Setiardja, A, Gunawan, 1993. Hak-Hak Asasi Manusia Berdasarkan Ideologi Pancasila, Yogyakarta: kanisius.

Silalahi, Daud, Lingkungan Sebagai Subjek Hukum dan Kewenagan LSM Lingkungan, Hukum dan Pembangunan, Agustus 1989.

Soemarwoto, Otto, 2004, Ekologi, Lingkungan Hidup dan Pembangunan, Penerbir Jembatan, Cetakan kesepuluh.

Suardi dan Muhammad, Tanggungjawab Negara Terhadap Pemenuhan Hak Atas Lingkungan Yang Sehat dan Bersih Dalam Prespektif Hak Asasi Manusia,laporan hasil peneitian, Fakultas Hukum Universitas Tadulako Tahun 2014. 
Suardi, B, Dg, Mallawa, Hak Gugat Organisasi Lingkungan Hidup Dalam Sistem Hukum Lingkungan Indonesia, Jurnal Penegakan Hukum Volume 3, Nomor 2 Juli 2006, Terakreditasi berdasarkan Keputusan Direktur Jenderal Pendidikan Tinggi Departemen Pendidikan Nasional Nomor 55/Dikti/2005 Tanggal 17 November 2005.

Sulbadana, 2010. Prinsip hukum Pelestarian Hutan dan Kaitannya Dengan Pemanasan Global,Unpad Press.

\section{B. Peraturan Perundang-Undangan}

Undang-Undang Nomor 32 tahun 2009 tentang Perlindungan dan Pengelolaan Lingkungan Hidup.

UU No. 39 tahun 1999 tentang Hak Asasi Manusia.

\section{Internet / media massa}

Harian Kompas, 19 Januari 2002.

Harian Kompas, 20 September 2003

Online bulleting, edisi Januari-Pebruari 2009, tata ruang, Gerakan Kota Hijau.

www.Bangazul.com./prinsip-prinsip pembangunan berkelanjutan. 